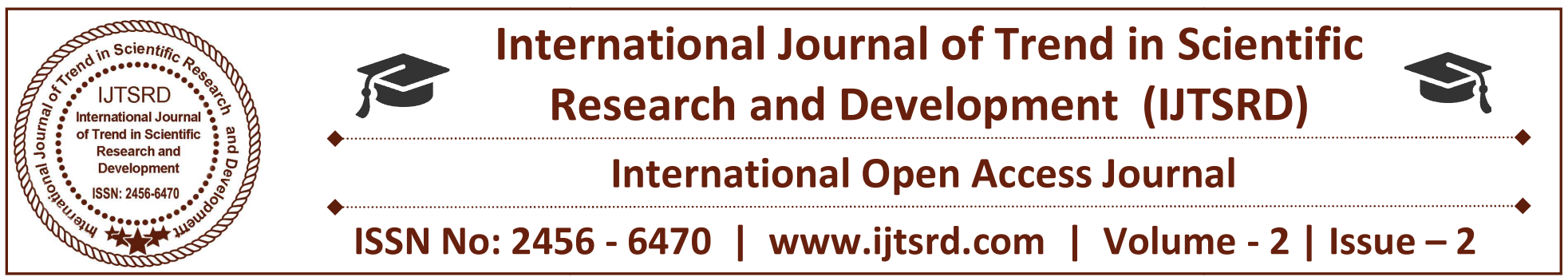

\title{
The Effect of Biographical Characteristics on Employee Motivational Force and their Tenure in Job: A study in Indian Academic Sector
}

\author{
Dr. Aditi Banerjee \\ Assistant Professor, T K R College of Engineering and Technology \\ (Osmania University), Yusufguda, Hyderabad, Telangana, India
}

\section{ABSTRACT}

In today's environment, organizations thrive and survive on human resources. Values, attitude, perception and behaviour of employees, which form this resource, influence their performance. Therefore, it has become important to realize organizational and individual goals, which in turn depend on selfmotivation as well as self-satisfaction. The study aims to measure the effect of the biographical characteristics (age, gender, educational qualifications and work experience) on employee motivational force and the tenure of the employees in Academic (Technical Education) Sectors in India. A quantitative methodology was used for the study and questionnaire method was used as the measuring instrument. Participants were 157 employees (randomly selected) from different Technical Academic Institutes in India. The four independent variables of our study were age, gender, educational qualification and work experience of employees and the dependent variables were employee motivational force and the tenure in job of the employees. The data was subjected to a number of statistical analyses such as T-test, Correlation, One way ANOVA and Regression Analysis. Results indicated that the biographical characteristics mainly educational qualification (positively significant relation) has a great influence on the motivational force of the academic professionals whereas gender and experience (positively significant relation) have great influences on the decision to turnover intention of the academicians. The present study revealed that the organizational managements and psychologists can consider different strategies and policies to motivate employees in work settings, and retaining the employees in the organizations.

Keywords: Motivational Force, Biographical Characteristics, Employee Job Tenure, Employee Retention

\section{Introduction}

Organizational effectiveness depends on its ability to achieve its stated objectives. According to Barnard (1938), organizational effectiveness refers to the degree to which operative and operational goals of the organization have been achieved. But, as has already been mentioned, achieving organizational objectives depends, to a large extent, on whether the organization possesses a motivated workforce or not. Acquiring and retaining talent have posed a major challenge in recent time, as professional employees are found to be always on the move today and loyalty and commitment seem to have taken a backseat, not appreciated much either at the individual or at the organizational level. Available research studies seem to indicate that employees generally look for some possible organizational outcomes while engaged in their job, such as a relatively stable employment, job security, opportunities for promotions and satisfactory compensations that results in a continuing relationship with their organization. This in fact brings our attention to the employee motivational issues. Even the competent employees (those with the expertise, knowledge, skills and behavioral attributes) would not 
necessarily do well, if they were not motivated. Thus, organizations wishing to retain its employees in order to ensure the long-term sustainability and competitive edge over other firms, must try to provide its employees with what they want from their job and from the company. As noted by Oosthuizen (2001), only a comprehensive theory of motivation may explain how human behavior is guided or focused in accordance to their levels of motivation of which valence or what people want from their job is only one component.

\section{Importance of Employee Motivation}

What is motivation? Motivation is described both as being intentional as well as directional. The word 'intentional' refers to the personal choice and persistence of action, while the word 'directional' denotes the presence of a driving force that aimed at achieving a specific goal. A motivated person is thus the one who is always aware of the fact that a specific goal must be achieved, and would direct his efforts towards attaining that goal (Nel et al., 2001).

Employee motivation remains a key issue for organizations today. With the rapidly changing environment in the age of globalization and open market scenario the solution to problems related with employee motivation is becoming increasingly complex. This is due, in part, to the fact that what motivates the employees' keeps on changing constantly (Bowen \& Radhakrishna, 1991). Organizations need to understand the need of the employees as well as ways to motivate them within the context of the roles they perform. The managers need to understand the fundamental components of motivation, and the underlying processes involved to develop a motivated workforce. A considerable amount of research has been devoted to unearth the possible linkage between pay and / or the nature of work to higher levels of employee motivation. Provisions of job enlargement, job enrichment, promotions, monetary and non-monetary compensation are all been considered by the researchers in this field. Higgins (2004) has identified ten most motivating factors in the work place viz. interesting work, good wages, full appreciation of work done, job security, good working conditions, promotions and growth in the organization, feeling of being in on things, personal loyalty to employees, tactful discipline, and sympathetic help with personal problems.

\section{Importance of Demographical Characteristics on Motivation}

Here in this literature we will get insight into worker motivation and how it may be affected by personal characteristics such as age, gender, educational qualification and work experience.

\section{Importance of Age on Employee Motivational Force}

Reudavey (2002) in the Australian aviation mentioned that there is no relationship between job satisfaction and age but Robbins (2001) pointed out that age exerts an influence on motivation. Jones Johnson and Johnson (2000) have found that older employees have the tendency to experience higher levels of motivation, compared to their younger counterparts. This has been supported by Sui, Spector, Cooper and Donald (2001), and in their research amongst managers, they have also found that age was positively related to motivation and mental wellbeing.

Solomon and Muhammad (2010) have shown that the teachers in the initial ages are less motivated than the teachers in the age group of 45 years and above, and unmarried teachers are more satisfied as compared to married teachers.

Although in a number of studies people could not find out any significant relationship between age and motivation (Bhargava \& Kelkar, 2000; Gouws, 1995; Jernigan, Beggs \& Kohut, 2002), but lots of other data suggested that older adults therefore adults in the later stages of their careers, are less motivated by the necessity to prove themselves through their achievements and they might be more driven by aspects such as meaningful work (Tolbert \& Moen, 1998). In an examination of motivational traits and tendencies in achievement settings in the workplace, Heckhausen (1997) found that middle-aged people means people between the age group of 30-40 years were less motivated towards achievement than younger adults. Kovach (1995) also found significant differences between age groups. According to his findings when people aged under-30, give high value on good wages, people between the age group 31 to 40 give importance to job security and the over-50 aged workers give most importance to support with their personal problems. It appears that as employees get older, they are less motivated by pay but they are much more motivated by the desire to achieve and 
master new skills. At the same time they also like to compete with their colleagues whereas the younger employees are just the opposite of that.

\section{Effect of Gender on Employee Motivational Force}

A huge no of research work is going on worldwide on gender to find out if there is any significant relationship exists between motivation and gender differences. For example Sousa-Poza (2003), in his research in Great Britain, has also found that the job satisfaction of females have declined substantially over the past decade, whereas the level of job satisfaction in males have remained fairly consistent. Furthermore, Al-Mashaan (2003) has found that the motivation levels of males are higher than those of females. It is thereby argued that males are utilising their competencies much more, compared to females who are more exposed to more sources of stress including those in the workplace as well as at home. But at the same time opposite to the abovementioned, Lambert et al. (2001) and other researchers, who have researched this area involving several different populations, have found that female employees reveal higher levels of job satisfaction as well as motivation than their male counterparts, across most settings.

Huddleston et al. (2002) found that female employees always have a stronger preference for aspects of their jobs that relate to security, such as pay and job security. Kovach (1995) in his research found out that women employees in the workplace pay considerably more importance to interpersonal relationships and communication than men. And he also revealed that women continue these activities to cope with their dual role as a homemaker as well as an employee, where both these aspects demand attention. From these results it seems that although women are more strongly motivated by goal achievement, they are simultaneously more fearful of failure than men, and also more inclined to focus on interpersonal and security-related characteristics of the job than men.

According to the study by Dgoldblatt (2008) in Kuwait in the hypothesis whether females are more committed and satisfied as compared to males the results of most of the studies are contradictory. According to him, there exist positive relationships between gender and job satisfaction and gender and organizational commitment, but these relationships are not significant. At the same time some studies also failed to show any significant relationship between gender and employee motivation (Gouws, 1995; Moon, 2000; Stinson \& Johnson, 1977).

\section{Effect of Educational Qualification on Motivational Force of Employees}

Lots of research works are also going on to find out if there is any significant correlation exists between motivation and educational qualification of the employees. Gazioglu and Tansel (2002) observed that graduates and post graduates people in the organizations have less job satisfaction than employees with lower levels of qualifications. So according to their research people with higher level of qualification have a lower level of motivation than people with lower level of educational qualification. Although Groot, Maassen and Van Den Brink (2002) have found that there is no significant effect of over qualification on job satisfaction or motivation of the employees. However, Reudavey (2001) also could not find a relationship between job satisfaction and educational level of the employees.

Huddleston et al. (2002) found that higher educated employees tend to be more powerfully motivated by intrinsic rewards such as praise and recognition, than their less educated counterparts. They termed this characteristic 'Recognition Valence', which means the importance or value attached to recognition. This finding was also supported by Western studies done by (Bellenger et al. 1984). The authors did not offer any possible explanation for this result but according to him the workers' reward preferences seem to change based on social factors such as education level, and on career progression. It simply means that people who are interested to pursue academic goals are generally more motivated by a sense of achievement than by financial rewards. At the same time many authors also could not found any significant relationship between educational qualification and employee motivation (Gouws, 1995; Moon, 2000; Stinson \& Johnson, 1977).

\section{Effect of Work Experience on Motivational Force of Employees}

Despite lots of research works done if occupational seniority has a significant relationship exist with motivation, several did not report any statistically significant relationship in this regard (Gouws, 1995; Stinson \& Johnson, 1977). But Kovach (1995) in his research found a statistically significant difference based on seniority, or organisational level. According 
to his findings in the lower-level employees were far more motivated by good wages than middle and higher level employees who tended to value job security and recognition more. This finding, namely that more senior employees are generally more strongly motivated by higher-order needs, such as achievement, personal growth and recognition, than by lower-order needs, such as pay as per the Maslow's need-hierarchy theory. Bellenger et al. (1984) also supported the same view.

According to Greenberg and Baron (1995), older employees are generally happier with their jobs than younger employees, while people who are more experienced in their jobs are more highly satisfied than those who are less experienced. Drafke and Kossen (2002) in their research also revealed the same view. The researchers state that job satisfaction typically increases with age as older workers have more work experience and generally have a more realistic view of work and life in comparison to their younger counterparts whereas the younger employees have an idealistic view of what work should be like but have less experience to utilize their knowledge, skills and expertise.

But at the same time many research works done on the relationship between motivation and occupational seniority or experience but several did not report any statistically significant relationship in this regard (Gouws, 1995; Stinson \& Johnson, 1977).

\section{Biographical Characteristics, Employee Job Tenure and Turnover Intention}

Tenure refers to the number of years an employee has spent working (Oshagbemi, 2003). The term 'turnover' refers to employee movements that create vacancies within an organizational unit (Beach, Brereton, and Cliff 2003, 62). These vacancies may be the result of resignations, transfers, retirements, dismissals, or the completion of fixed term contracts. Researchers have done a wide range of literature review on this particular issues related to the reasons for and consequences of employee loss. Management of any organization is facing a huge challenge to deal with turnover intention of its employees in the industries. A literature review has been done in order to know the reasons for and consequences of employee turnover and to have a fair understanding of the strategies that could be adopted by companies. Hale (1998) stated that employers cited recruitment costs of $50 \%$ to $60 \%$ of an employee's first year's salary and up to $100 \%$ for certain specialized, highskill positions. Bowen and Shuster (1986) stated that while all the other resources (raw material, financial support etc) of an organization are important for its success then it should be the priority of any organization to attract and retain the best quality talent that separates it from the others. According to Abbasi and Hollman (2000) excessive employee turnover often engenders far reaching consequences and at the extreme may endanger efforts to attain the organizational objectives.

In different empirical studies it has been indicated that demographic variables are relevant with employee turnover intentions (William and Hazer, 1986). Cotton and Tuttle, 1986; Morrow, 1983 and Gregersen and Black, 1982 in their research have found out that age, income and tenure are identified as negatively related to turnover intentions. Several studies have reported negative relationship between turnover intention and three demographic factors such as age, tenure, and income level of the employees (Arnold \& Feldman, 1982; Cotton \& Tuttle, 1986; Gerhart, 1990; Mobley et. al, 1979; Price \& Mueller, 1986; Wai \& Robinson, 1998; Weil \& Kimball, 1995, and others). In case of educational qualifications it has been also found out that it is positively associated with turnover intention suggesting that the more educated employees quit more often (Berg, 1991; Cotton \& Tuttle, 1986). But findings of the studies on the relationship between gender and turnover are mixed as Cotton and Tuttle (1986) and Weisberg and Kirschenbaum (1993) revealed in their research that female employees more likely to leave than males whereas Berg (1991), Miller and Wheeler (1992) reported no relationship between gender and turnover. Recently in a research Elaine (1997) and Summers and Hendrix (1991) found males more likely to quit than females. However, in their meta-analysis, Griffeth et al. (2000) show only a negligible difference between men and women in terms of turnover intention (women are slightly more likely to leave their jobs than men). In case of age the studies revealed that younger employees are more likely to take risks at the beginning of their careers. They are also more likely to accept positions that are below their abilities and expectations at the beginning of their career and always on a move to better opportunities. Griffeth et al. 2000 in their research also supports the negative age-turnover relationship. 
Worker turnover has been of interest to both managers and researchers across a wide array of disciplines for obvious reasons. In response to employee turnover, particularly voluntary turnover, Mobley and colleagues (Mobley, Griffeth, Hand \& Meglino, 1979) proposed four core antecedent factors as predictors of employee turnover. First are demographic characteristics that influence a person's decision whether to remain with or leave a job. Secondly, lack of job satisfaction, which leads to a cognitive withdrawal process stressing turnover intention. Thirdly, the work environment factors are found to have significant relationship with employee job satisfaction, and that in turn shapes turnover intention. Finally, it is the turnover intent, which influences voluntary turnover.

\section{Globalization, India and Education Service Industry}

The service industry forms a backbone of social and economic development of a region. It has emerged as the largest and fastest-growing sectors in the world economy, making higher contributions to the global output and employment. Its growth rate has been higher than that of agriculture and manufacturing sectors. It is a large and most dynamic part of the Indian economy both in terms of employment potential and contribution to national income. It covers a wide range of activities, such as education, trading, transportation and communication, financial, real estate and business services, as well as community, social and personal services. In India, services sector, as a whole, contributed as much as 68.6 per cent of the overall average growth in gross domestic product (GDP) between the years 2002-03 and 2006-07 . ("Service Sector in India"; 21-07-2007; Indian economy). The most important services in the Indian economy has been health and education. They are one of the largest and most challenging sectors and hold a key to the country's overall progress.

The era of economic liberalization has ushered in a rapid change in the service industry. As a result, over the years, India is witnessing a transition from agriculture-based economy to a knowledge-based economy. The knowledge economy creates, disseminates, and uses knowledge to enhance its growth and development.

The education system has been increasing globally. Now more people are investing their time and money in the education business than in the past. Although all levels of education have experienced a huge expansion, but the rate of growth perhaps, has been greatest at the higher education level. Between 1991 and 2005, the number of students enrolled worldwide in different institutions for higher studies is more than doubled from 68 to 137.9 million students (UNESCO Institute for Statistics - UIS, 2007).

As we all know that there are several reasons why the higher education system should be expanded. The first reason behind this is a huge increase in the lower level of education system. This expansion has been happened because of the voluntary demand for education and also in response to public action. The law for compulsory primary education has become a national commitment and international support to achieve the Education for All (EFA) goals.

The second reason behind this is that because of the high demand of university graduates for the public service sector and in most of the developing countries the public sector used to be the largest employer of university graduates. But due the reason of globalization the private sector have promoted of their economies whereas employment in the public sector has been declined in many countries. In fact we can say that the slowdown in employment generation in the public sector has been compensated by employment creation in the private sector. At the same time it has been realized that due to globalization, the requirements for skills, knowledge and aptitude has also been changed in a huge way by the companies. So to compete with the changing demands of time many countries have universalized their school education and at the same time changed their higher education systems.

The third reason for expansion of higher education is better job opportunities and higher salary expectations of the students pursuing studies in domestic as well as private institutions and because of this reason the number of students has increased in cross-border institutions, it has become almost double to 2.7 million in the last decade.

The Knowledge economies have grown faster than any other and many of them have continued a growth over the past decades. And at present it is in the centre of development. Because of the huge growth in knowledge economies employment opportunities have expanded globally on two sides. Firstly, there has been an increase in employment in the developed countries where production is more knowledge-based, 
skill requirements are high and have attracted highly skilled workers from other countries. And secondly, there has been an increase in domestic employment opportunities in developing countries due to the increase in foreign direct investment (FDI) and the growth of private enterprises, including firms focusing on outsourcing because of globalization. But at the same time it is to be seen that the skill requirements in the knowledge economy are not only different from traditional manufacturing sector, but also the level of skills required and the qualifications demanded for job entry are also high and continuing to get higher. Studies show that, in countries such as Canada, nearly 70 per cent of all new jobs will require a post-secondary level of education (International Labor Office - ILO, 2004).

It is a very well known fact to all of us that the technical education system in India has undergone a huge change in last 20 years as compared to previous 50 years. This has seen enormous private participation and huge growth of engineering and management colleges not only in terms of numbers of colleges but also numbers of students enrolled. ("Indian Higher Education Sector: Heading towards Transformation"; International Conference on Technology and Business Management March 28-30, 2011)

\section{The Specific Objectives of the Study}

More specifically, the objectives of the present research are:

- To determine whether there exists any relationship between the age of the employees and their motivational force in Academic sector.

- To determine whether there exists any relationship between the gender of the employee and their motivational force in Academic sector.

- To determine whether there exists any relationship between employees' educational qualification and their motivational force in Academic sector.

- To determine whether there exists any relationship between employees' work experience and their motivational force in Academic sector.

- To identify the relationship that may exist between employee biographical characteristics and their tenure in the present job in Academic sector.
The hypotheses of the present study are framed in the form of Null Hypotheses.

- Null Hypothesis 1: There is no relationship whatsoever between the age of the employees and the level of their motivational force in both Academic and Information Technology (IT) sectors.

- Null Hypothesis 2: There is no relationship whatsoever between Employees' Experience (in years) and the level of their motivational force in both Academic and Information Technology (IT) sectors.

- Null Hypothesis 3: There is no relationship whatsoever between the gender of the employees and their levels of motivational force in both Academic and Information Technology (IT) sectors.

- Null Hypothesis 4: There is no relationship whatsoever between Employees' Educational Qualification and the level of their motivational force in both Academic and Information Technology (IT) sectors.

- Null Hypothesis 5: There is no relationship whatsoever between the biographical characteristics and their tenure in present job of the employees in Academic sector.

\section{Sampling}

Two specific service industries were considered for the purpose of the present study, viz. Technical Academic Sector. The method of stratified random sampling was employed to select employees from various institutes belonging to this sector as sample for the study. The size of the sample thus selected is 157.

\section{Tool Used}

'What People Want from Their Job', a standardized 14-item questionnaire by Pareek (2002) was followed to identify employees' valence for different job outcomes along with an Personal Information Sheet that records the respondents' the details of demographic data (viz. gender, age in years, educational qualifications, experience or years of service).

\section{Hypothesis of the Study}


The 14-item questionnaire, 'What People Want from Their Job' as well as the Personal Information Sheet was administered individually to each of the respondents to collect the required information.

\section{Statistical Techniques Followed}

The Statistical Package for the Social Sciences (SPSS), Version 20, was utilised to analyse the data with frequency tables and graphical illustrations to provide information on key demographic variables in this study. The upper level of statistical significance for null hypothesis testing was set at 5\%. All statistical test results were calculated at the 2-tailed level of significance in accordance with the nondirectional hypotheses presented (Sekaran, 2000).

\section{Description of the Sample Gender}

As shown in Exhibit 1, almost sixty eight percent of the present sample in Academic sector is found to be male, while the rest (31 percent) are female.

Exhibit 1: Percentage of Male and Female Distribution in Academic Sector

\begin{tabular}{|c|c|c|}
\hline \multicolumn{3}{|c|}{ Percentage of Respondents } \\
\hline Male & Female & Total \\
\hline 68.42 & $31.57=$ & 100 \\
\hline
\end{tabular}

\section{Age in Years}

As shown in Exhibit 2, age of the employees' concentrates in the Young Category, comprising $41.44 \%$ of the sample while in the Middle aged group $40.13 \%$ of the respondents belong and $12.5 \%$ of the respondents are there in the Upper-Middle section. Very few people is found to belong to the Old category $(5.92 \%)$. However, the average age in Academic sector is thirty-four years (Exhibit 3), which indicates the fact that most of the respondents belong to middle aged group.

Exhibit 2: Percentage of Age Distribution of the Sample in Academic Sector

Percentage of Sample Having

\begin{tabular}{|l|l|l|l|}
\hline $\begin{array}{l}\text { Young (23- } \\
30 \text { years) }\end{array}$ & $\begin{array}{l}\text { Middle } \\
\text { Aged (31-40 } \\
\text { years) }\end{array}$ & $\begin{array}{l}\text { Upper } \\
\text { Middle (41- } \\
50 \text { years) }\end{array}$ & $\begin{array}{l}\text { Old (50+ } \\
\text { years) }\end{array}$ \\
\hline 41.44 & 40.13 & 12.5 & 5.92 \\
\hline
\end{tabular}

Exhibit 3: Mean and Standard Deviation of Age (in years) in Academic Sector

\begin{tabular}{|l|l|}
\hline Age of the Sample \\
\hline Mean (in Years) & 34.53 \\
\hline Standard Deviation & 8.25 \\
\hline
\end{tabular}

\section{Educational Qualification}

In the present study, educational qualification is considered in terms of the number of years spent in completing the study. Four groups of educational level have been created: Group 1 is the one where respondents have 16 years of education and referring to the technical graduates (BE/BTech) and Group 2 having 17 years of education, referring to graduation with a post graduates (PGDBA/MBA/MA/M.Com/M.Sc etc) qualification, Group 3 is the one having 18 years of education (BE/B.Tech + MBA/PGDBA) and the Group 4 have the highest level of educational qualification $(\mathrm{Ph} . \mathrm{D})$ with 20 years of education.

As shown in Exhibit 4, the majority of the respondents (about $64.47 \%$ ) in Academic Sector have 17 years of education, with only $5.26 \%$ respondents having 16 years of education and $31.30 \%$ respondents are having 20 years of education that means Doctoral degree.

Exhibit 4: Percentage of the Sample Having Different Levels of Educational Qualification (in years) in Academic Sector Percentage of Sample Having

\begin{tabular}{|l|l|l|}
$\begin{array}{l}\text { B.E/B.Tech (16 } \\
\text { years) }\end{array}$ & $\begin{array}{l}\text { MBA / PGDBA } \\
\text { (17 years) }\end{array}$ & $\begin{array}{l}\text { Ph. D } \\
\text { (20 years) }\end{array}$ \\
\hline 5.26 & 64.47 & 31.30 \\
\hline
\end{tabular}

Exhibit 5: Mean and Standard Deviation of Educational Qualification in Academic Sector

Educational Qualification of the Sample

\begin{tabular}{|l|l|}
\hline Mean (in Years) & 17.85 \\
\hline Standard Deviation & 1.43 \\
\hline
\end{tabular}

\section{Experience (Years of Service):}

The years of service or experience of the respondents are categorized in to five groups: Group 1: 6 months2 Years, Group 2: 2.5-5 Years, Group 3: 6-10 years and Group 4 represents people with more than 10-15 years of experience and Group 5 represents people with more than 15 years of experience.

As it is seen in the Exhibit 6, in Academic sector the highest number of respondents $(29.60 \%)$ falls under 
International Journal of Trend in Scientific Research and Development (IJTSRD) ISSN: 2456-6470

Group 2 followed by Group 3 (24.34\%). Group 1 has only $23.68 \%$ of the respondents while only $9.86 \%$ people are left in Group 4 with more than ten years of experience. And we have $12.57 \%$ respondents falls under group 5 that means people with more than 15 years of experience.

Exhibit 6: Percentage of the Sample Having Different Levels of Experience (Years of Service) in Academic Sector

\begin{tabular}{|l|l|l|l|l|}
\hline \multicolumn{5}{|l|}{ Percentage of Sample Having } \\
\hline $0.6-2$ & $2.5-5$ & $5.5-10$ & $10-15$ & $15+$ \\
Years & Years & Years & Years & Years \\
\hline 23.68 & 29.60 & 24.34 & 9.86 & 12.57 \\
\hline
\end{tabular}

Exhibit 7: Mean and Standard Deviation of Experience in Academic Sector

Experience of the Sample

\begin{tabular}{|l|l|}
\hline Mean (in Years) & 7.60 \\
\hline Standard Deviation & 7.42 \\
\hline
\end{tabular}

\section{Employee Tenure in the present Job (in Years)}

The highest number of employees (as high as 54\%) in the Academic sector is found to have only a maximum of two years of job tenure (Exhibit 8). Employees having tenure of up to five years in this sector is found to be $35.52 \%$ while those having the tenure of more than five years in the present job are found to be rather few $(10.54 \%)$. The average tenure of the employees in Academic sector is less than three years (Exhibit 9).

Exhibit 8: Percentage of the Sample Having Different Tenure (in Present Job) in Academic Sector

\begin{tabular}{|l|l|l|}
\hline \multicolumn{3}{|c|}{ Percentage of Sample Having Tenure in the Present Job of } \\
\hline 0.6-2 Years & $2.5-5$ Years & $5+$ Years \\
\hline 53.94 & 35.52 & 10.54 \\
\hline
\end{tabular}

Exhibit 9: Mean and Standard Deviation of Tenure (in the Present Job) of the sample in Academic Sector

\begin{tabular}{|l|l|}
\hline Tenure in the Present Job of the Sample \\
\hline Mean (in Years) & 2.77 \\
\hline Standard Deviation & 2.11 \\
\hline
\end{tabular}

\section{Findings of the Study}

Table 1: Inter correlations of all variables: Tenure in Present Job, Motivational Force and All Demographic Variables-Age, Gender, Educational Qualification and Experience in Academic Sector

\begin{tabular}{|c|c|c|c|c|c|c|c|}
\hline & & Age & Gender & $\begin{array}{l}\text { Educational } \\
\text { Qualification }\end{array}$ & Experience & $\begin{array}{l}\text { Tenure in } \\
\text { Present Job }\end{array}$ & $\begin{array}{l}\text { Motivational } \\
\text { Force }\end{array}$ \\
\hline \multirow[t]{3}{*}{ Age } & $\begin{array}{l}\text { Pearson } \\
\text { Correlation }\end{array}$ & 1 & & . & & & \\
\hline & Sig. (2-tailed) & & & & & & \\
\hline & $\mathrm{N}$ & 152 & & & & & \\
\hline \multirow[t]{3}{*}{ Gender } & $\begin{array}{l}\text { Pearson } \\
\text { Correlation }\end{array}$ & $.393^{* *}$ & 1 & & & & \\
\hline & Sig. (2-tailed) & .000 & & & & & \\
\hline & $\mathrm{N}$ & 152 & 152 & & & & \\
\hline \multirow[t]{3}{*}{$\begin{array}{l}\text { Educational } \\
\text { Qualification }\end{array}$} & $\begin{array}{l}\text { Pearson } \\
\text { Correlation }\end{array}$ & $.534^{* *}$ & $.183^{*}$ & 1 & & & \\
\hline & Sig. (2-tailed) & .000 & .024 & & & & \\
\hline & $\mathrm{N}$ & 152 & 152 & 152 & & & \\
\hline
\end{tabular}


International Journal of Trend in Scientific Research and Development (IJTSRD) ISSN: 2456-6470

\begin{tabular}{|c|c|c|c|c|c|c|c|}
\hline \multirow[t]{3}{*}{ Experience } & $\begin{array}{l}\text { Pearson } \\
\text { Correlation }\end{array}$ & $.915^{* *}$ & $.336^{* *}$ & $.465^{* *}$ & 1 & & \\
\hline & Sig. (2-tailed) & .000 & .000 & .000 & & & \\
\hline & $\mathrm{N}$ & 152 & 152 & 152 & 152 & & \\
\hline \multirow[t]{3}{*}{$\begin{array}{l}\text { Tenure in } \\
\text { Present Job }\end{array}$} & $\begin{array}{l}\text { Pearson } \\
\text { Correlation }\end{array}$ & $.529^{* *}$ & $.337^{* *}$ & .134 & $.564^{* *}$ & 1 & \\
\hline & Sig. (2-tailed) & .000 & .000 & .099 & .000 & & \\
\hline & $\mathrm{N}$ & 152 & 152 & 152 & 152 & 152 & \\
\hline \multirow[t]{3}{*}{$\begin{array}{l}\text { Motivational } \\
\text { Force }\end{array}$} & $\begin{array}{l}\text { Pearson } \\
\text { Correlation }\end{array}$ & -.053 & -.090 & $.197^{*}$ & -.029 & $-.170^{*}$ & 1 \\
\hline & Sig. (2-tailed) & .515 & .270 & .015 & .720 & .036 & \\
\hline & $\mathrm{N}$ & 152 & 152 & 152 & 152 & 152 & 152 \\
\hline
\end{tabular}

**. Correlation is significant at the 0.01 level (2-tailed)

*. Correlation is significant at the 0.05 level (2-tailed).

\section{Relationship between Demographic Variables and Motivational Force:}

Motivational Force and Age as well as Experience of Employees:

Table 1 indicates that there is no statistically significant correlation exists between Age and Experience with employee Motivational Force as the corresponding $\mathrm{p}$ values are $(\mathrm{r}=-0.053, \mathrm{p}<0.515)$ and $(\mathrm{r}=-0.029, \mathrm{p}<0.072)$ in academic sector.

Motivational Force and Gender of Employees:

Table 2: t-test to Identify Differences in Employee Motivational Force based on Gender in the Academic Sector

\begin{tabular}{|c|c|c|c|c|c|c|c|c|}
\hline & \multicolumn{7}{|c|}{ t-test for Equality of Means } \\
\hline & & \multirow[t]{2}{*}{$\mathbf{T}$} & \multirow{2}{*}{ Df } & & \multirow{2}{*}{$\begin{array}{l}\text { Mean } \\
\text { Difference }\end{array}$} & \multirow{2}{*}{$\begin{array}{l}\text { Std. Error } \\
\text { Difference }\end{array}$} & \multicolumn{2}{|c|}{$\begin{array}{l}95 \% \text { Confidence Interval } \\
\text { of the Difference }\end{array}$} \\
\hline & & & & & & & Lower & Upper \\
\hline \multirow[t]{2}{*}{$\begin{array}{l}\text { Motivat } \\
\text { ional } \\
\text { Force }\end{array}$} & $\begin{array}{l}\text { Equal } \\
\text { variances } \\
\text { assumed }\end{array}$ & 1.108 & 150 & .270 & $4.308=4 / 2$ & 3.889 & -3.377 & 11.993 \\
\hline & $\begin{array}{l}\text { Equal } \\
\text { variances not } \\
\text { assumed }\end{array}$ & 1.074 & 85.048 & .286 & 4.308 & 4.010 & -3.665 & 12.280 \\
\hline
\end{tabular}

From the Table 2, the t-test result shows that the two-tailed p-value is 0.286 . So we can conclude that there is not any significant difference between employee motivational force between male and female employees in the Academic Sector. 
Figure 1: Distribution of Mean Employee Motivational Force across Genders to Identify Possible Overlapping (Error Bar Chart) In Academic Sector

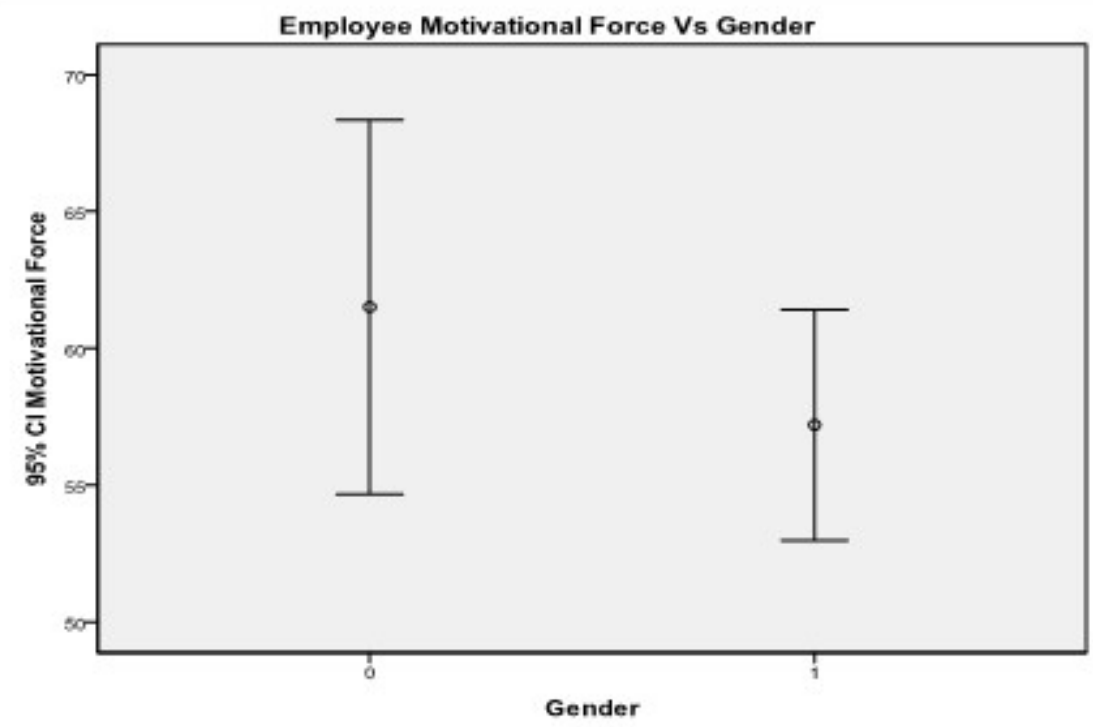

Note:

$1=$ Male

$0=$ Female

Form the figure 1 it is clear that there is not a very significant difference in the level of motivational force of the male and female employees in the Academic Sectors.

Table 3: ANOVA to Identify Differences in Employee Motivational Force based on Different levels of Educational Qualifications in Academic Sector

\begin{tabular}{|l|l|l|l|l|l|}
\cline { 2 - 6 } \multicolumn{1}{l|}{} & Sum of Squares & Df & Mean Square & F & Sig. \\
\hline Between Groups & 2958.962 & 2 & 1479.481 & 3.054 & .050 \\
\hline Within Groups & 72170.820 & & & \\
\hline Total & 75129.782 & 149 & 484.368 & & \\
\hline
\end{tabular}

As evident from the Table 3, between groups variability due to educational qualification is 2 while the within group variability arising due to random error is 149 . The $\mathrm{F}$ value is $3.054(\mathrm{p}<0.05)$. Therefore we can say that a significant difference lies between employee motivational force based on different level of education in Academic Sectors. Now to understand the relative degree of employee motivational forces across different level of Educational Qualification, we have to conduct a further analysis to derive the required multiple comparisons as presented in Table 4 below.
Table 4: Post Hoc: Multiple Comparisons between Employees Motivational Forces based on Different Level of Education

\begin{tabular}{|l|l|l|l|}
\hline $\begin{array}{l}\text { (I)Educational } \\
\text { Qualification } \\
\text { (Yrs) }\end{array}$ & $\begin{array}{l}\text { (J)Educational } \\
\text { Qualification } \\
\text { (Yrs) }\end{array}$ & $\begin{array}{l}\text { Mean } \\
\text { Difference } \\
(\mathrm{I}-\mathrm{J})\end{array}$ & $\begin{array}{l}\mathrm{p} \text { - } \\
\text { Value }\end{array}$ \\
\hline $\mathbf{1 6}$ & 17 & -8.10441 & .318 \\
& 20 & -16.27321 & .055 \\
\hline $\mathbf{1 7}$ & 16 & 8.10441 & .318 \\
& 20 & $-8.16879^{*}$ & .040 \\
\hline $\mathbf{2 0}$ & 16 & 16.27321 & .055 \\
& 17 & $8.16879^{*}$ & .040 \\
\hline
\end{tabular}

Note:

- 16 Yrs- B.E/B.Tech

- 17 Yrs- B.Sc/B.A/B.Com +PGDBA/MBA 
- 20 Yrs- PH.D

*. The mean difference is significant at the 0.05 level The results presented in Table 4 indicate that employees with twenty years of educational qualification apparently are having the higher motivational force score in comparison to their counterpart employees with sixteen and seventeen years of educational qualification as well. When we consider the motivational force scores of the employees with Twenty years and well as seventeen years of educational qualification respectively, employees with twenty years of qualification found to possess a significantly higher level of motivational force than their counterparts with seventeen years of education. The mean difference between the employee motivational scores in these two educational level is found to be $8.16879(\mathrm{p}<.05)$. When the motivational scores of employees with twenty years and sixteen years of educational qualification respectively are compared, employees with twenty years of qualification found to possess a significantly higher level of motivational force than their counterparts with sixteen years of education with the mean difference being $16.27321(\mathrm{p}<.06)$. At last when we consider the motivational force score between seventeen years and sixteen years of education we can find the mean difference $8.10441(\mathrm{p}<0.318)$. Though the mean difference is not statistically significant but we can find that employees with seventeen years of educational qualification are having higher motivational force than employees with sixteen years of educational qualification. Thus we find that the employees with twenty years of educational qualification are having the highest motivational force score and employees with sixteen years of educational qualification are having the lowest motivational force scores while the motivational force of the employees with seventeen years of educational qualification come in between.

Findings Based on Regression Analysis:

Predicting Employee Motivational Force from Different Demographic Variables in Academic Sector:

Table 5: Regression Analysis Results for Predicting Employee Motivational Force in Terms of the Demographic variables, viz. Age, Gender, Educational Qualification and Experience in Academic Sector Model Summary ${ }^{d}$

\begin{tabular}{|c|c|c|c|c|c|c|c|c|}
\hline Variable & $\mathbf{R}$ & R Square & $\begin{array}{l}\text { Adjusted-R } \\
\text { Square }\end{array}$ & $\begin{array}{l}\text { F } \\
\text { Change }\end{array}$ & Beta & Df & $\mathrm{T}$ & $\mathbf{P}$ \\
\hline $\begin{array}{l}\text { Educational } \\
\text { Qualification }\end{array}$ & .19 & .037 & $\begin{array}{l}.030 \\
245\end{array}$ & 5.721 & .305 & 150 & 3.27 & $\begin{array}{l}.018 \\
*\end{array}$ \\
\hline Age & $.264^{\mathrm{b}}$ & .070 & .057 & 5.297 & -.214 & 149 & -2.30 & $\begin{array}{l}.023 \\
*\end{array}$ \\
\hline
\end{tabular}

Dependent Variable: Motivational Force

A stepwise regression was performed, whereby employee motivational force was regressed on demographic factors. The results are summarized in Table 5. The results indicate that demographic factors (age and educational qualification) significantly predicted motivational force of the employees in academic sector. As we can see from the table, the $F$ value of educational qualification 5.721 is significant $(\mathrm{p}<.018), \mathrm{R}=0.192$, and $\mathrm{R}$ square $=.037$. It explains $3.7 \%$ of the total variance in employee motivational force. The coefficient part shows that the $t$ value (3.275) of educational qualification is significant with a beta weight of 0.305 . Recalling the findings of correlation test presented in Table 1 educational qualification has a significant and positive relationship $(\mathrm{r}=.197, \mathrm{p}<.015)$ with employee motivational force. And when we define age, the $\mathrm{F}$ value of 5.297 is also significant $(\mathrm{p}<.023), \mathrm{R}=0.264, \mathrm{R}$ square $=.070$. Age is another demographic variable of the present study that might affect negative significant role in influencing employee motivational force and that it explains $7 \%$ of the total variance in motivational force of the employees in academic sector. The coefficient part shows that the $t$ value $(-2.302)$ of age is significant with a beta weight of -0.214 . Recalling the findings of correlation test presented in Table 1 age has a negative relationship $(\mathrm{r}=-.053)$ with motivational force of the employees in the academic Sector. So we can say that age and education qualification made significant separate contributions to the prediction of employee motivational force in the academic sector. 
Predicting Tenure in present job from Motivation and other Demographic Variables in Academic Sector:

Table 6: Regression Analysis Results for Predicting Tenure in Present Job in Terms of Employee Motivational Force and Other Demographic variables, viz. Age, Gender, Educational Qualification and Experience in Academic Sector Model Summary ${ }^{d}$

\begin{tabular}{|l|l|l|l|l|l|l|l|l|}
\hline Variable & R & R Square & $\begin{array}{l}\text { Adjusted-R } \\
\text { Square }\end{array}$ & F Change & Beta & Df & T & P \\
\hline Experience & $.564^{\mathrm{a}}$ & .318 & .314 & 69.962 & .591 & 150 & 7.570 & $.000^{* *}$ \\
\hline Gender & $.585^{\mathrm{b}}$ & .343 & .334 & 5.538 & .177 & 149 & 2.549 & $.020^{*}$ \\
\hline $\begin{array}{l}\text { Educational } \\
\text { Qualification }\end{array}$ & $.608^{\mathrm{c}}$ & .370 & .357 & 6.365 & -.186 & 148 & -2.52 & $.013^{*}$ \\
\hline
\end{tabular}

Dependent Variable: Tenure in Present Job

$* * \mathrm{p}<.01$

$* \mathrm{p}<.05$

A stepwise regression was performed, whereby tenure was regressed on demographic factors and motivational force. The results are summarized in Table 6. The results indicate that demographic factors (experience, gender and educational qualification) significantly predicted tenure of employees as can be seen from the table 6.The $\mathrm{F}$ value of experience is 69.962 which is highly significant $(\mathrm{p} /<.000), \mathrm{R}=$ 0.564 , $\mathrm{R}$ square $=0.318$. This means that experience plays significant role in influencing tenure of the employees and it explains $31.8 \%$ of the total variance in tenure. The coefficient part shows that the $t$ value (7.570) of experience is highly significant with a beta weight of 0.591 . Recalling the findings of correlation test presented in Table 1 experience has a significant and positive relationship $(\mathrm{r}=.564, \mathrm{p}<.000)$ with tenure. And when we define gender, the $F$ value of 5.538 is also significant $(p<.020), R=0.585, R$ square $=0.343$. This means that gender also plays significant role in influencing tenure and that it explains $34.3 \%$ of the total variance in tenure. The coefficient part shows that the $t$ value (2.549) of gender is significant with a beta weight of 0.177 . Recalling the findings of correlation test presented in Table 1 shows gender has a significant and positive relationship $(\mathrm{r}=.337, \mathrm{p}<.000)$ with tenure. And the other most important factor which has a significant role in prediction of tenure of the employees in their present job in academic sector is educational qualification. In the case of educational qualification the $F$ value of 6.365 is significant $(p<.013), R=$ $0.604, \mathrm{R}$ square $=0.370$. This means that educational qualification plays significant role in influencing tenure and that it explains $37 \%$ of the total variance in tenure. The coefficient part shows that the $t$ value (2.523) of educational qualification is negatively

significant with a beta weight of -0.186 . So we can say that in academic sector educational qualification has a negative correlation with tenure of the employees that means more qualified people have a short tenure in the job in academic sector.

\section{Discussion}

\section{Different Demographic Variables and Their Possible Impact on Employee Motivational Force:}

Relationship between Emplovee Age and Their Motivational Force

From the Table 1 we can observe that employee motivational force in academic sector seems to go downward with the advance of age, as revealed by the inverse relationship shown between these two variables. This is in contrast to the common belief that aged people are better motivated. However, the strength of the relationship between employee motivation and their age is decidedly weak and far from being statistically significant $(\mathrm{r}=-0.053$, $\mathrm{p}<0.515)$.

Schulze and Steyn (2003) nevertheless found that age had a major impact on the motivation levels of educators. In a survey conducted by research house Catalyst in the United States in 2001 reported that between the age group of 20-27 years educators were committed to marriage, children or job mobility and were trying to build a stable future whereas educators between 28-33 years of age were found to deal with career issues, marriage and parenting more whereas educators between 34-39 years age are found to question their accomplishment or lack thereof, 
resulting in feeling of stress, which in turn found to have an impact on the level of motivation.

Thus, the findings of the present study seem to reject Null Hypothesis 1, viz. there is a negative relationship whatsoever between the age of the employees and their level of motivational force.

\section{Relationship between Emplovees' Experience and} Their Motivational Force

Interestingly, the present research seems to indicate a moderately negative relationship between employees' experience on their current job and their level of motivational force $(\mathrm{r}=-0.029, \mathrm{p}<0.720)$. This is shown in Table 1. Thus, the levels of motivational force of the members of the teaching fraternity tend to decrease with the passing years in their job. It could possibly be as people may start feeling stagnated and tend to lose hope for further development of their career progression after spending a longish period of time in a particular position. The present finding seems to be in contrary to the common belief that longer one stays with the organization, the better motivated the individual becomes. Many a researcher have however reported the similar findings as obtained in the present study ( Bellenger et al., 1984), though some research findings lend support to the commonly held belief (Schulze and Steyn's, 2003).

Thus, the findings of the present study seem to accept our Null Hypothesis 2, viz. there is no relationship whatsoever between the level of experience of the employees and their motivational force.

\section{Relationship between Gender of the Employees and} Their Level of Motivational Force

As is shown in Table 2, the difference between the mean motivational forces of male and female employees engaged in Academic Sector is not found to be statistically significant $(p<0.286)$. Thus, we may say that there is no significant difference between the motivational force of male and female employees in the academic Sector. Women in the Academic Sector today are found to be equally keen as their male counterpart in terms of the level of motivational force in the context of work organization. This is again contrary to the past findings by Sousa-Poza (2003), Al-Mashaan (2003) and Lambert et al. (2001). They all have found significant differences in work motivation and job satisfaction between males and females. According to Al-Mashaan (2003), the levels of job satisfaction of males are found to be higher than those of females. Sousa-Poza (2003) also found that the level of job satisfaction of females in Great
Britain has declined substantially over the past decade, whereas the level of job satisfaction in males remained fairly consistent. Lambert et al. (2001) and other researchers using several different populations have however found that females tend to show significantly higher levels of job satisfaction than their male counterparts. Several researchers have, however, found that the relationship between gender and job satisfaction have yielded contradictory results (Chiu, 1998).

Thus, the findings of the present study seem to accept our Null Hypothesis 3, viz. there is no relationship whatsoever between gender of the employees and their motivational force.

\section{Relationship between Employees' Educational Qualifications and Their Motivational Force}

The findings of the present study seems to clearly indicate the existence of a strong positive relationship $(\mathrm{r}=.197, \mathrm{p}<.050)$ between the educational qualification of the employees and their levels of motivational force, as measured by the multiplicative model (refer to Table 4). The more educated the faculty members in the technical and professional education, the higher their levels of motivational force. In other words, the willingness of the members of the teaching fraternity to put in more effort into their teaching seems to increase significantly with their levels of educational qualifications). Thus, the difference between the mean motivational force scores of employees having twenty years of education and those having seventeen years' of education is found to be $8.17(\mathrm{p}<0.05)$. Similar trend prevails when the mean motivational force scores of employees with twenty years of experience are compared with that of employees having seventeen years of experience, with the mean difference becoming even larger $(p<0.06)$. Thus, technical and professional teachers having a masters or a doctoral qualification are certainly more motivated than those with a B-Tech or postgraduate qualification. This could possibly be due to the employees' increased capability leading to an enhanced self-efficacy or expectancy, a major component of the three factor multiplicative model of employee motivational force. Similar trend prevails when the mean motivational force scores are compared between employees with seventeen years of experience vis-à-vis those with having sixteen years of experience, though in the last case, the difference fails to reach the level of statistical significance. Schulze and Steyn's (2003) found a similar trend in their study involving 
educators with their willingness to put in more effort increases with their level of education. Johnson and Johnson (2000) in their study at American postal services where they found that perceived overqualification have a negative impact on the dimensions of job satisfaction. Gazioglu and Tansel (2002) also found more or less similar result and reported that graduate and postgraduate employees tend to have lesser degrees of job satisfaction than those with lower levels of educational qualification.

Thus, the findings of the present study seem to reject Null Hypothesis 4, viz. there is no relationship whatsoever between the educational qualifications of the employees and their level of motivational force score as measured through the multiplicative model of motivation.

\section{Discussion based on Regression Analysis \\ Predicting Emplovee Motivational Force from Different Demographic Variables}

On the basis of the data of the present study in the Academic Sector (Table 5), the regression equation for predicting employee motivational force from the demographical characteristics is given below:

\section{Employee Motivational Force $=-6.038+4.738$ (Educational Qualification) -0.579 (Age)}

Thus, employee demographic factors such as educational qualification and age are found to be important predictors of motivational force in the Academic sector, educational qualification explaining $3.7 \%$ and age negatively explaining $7 \%$ of the variance respectively. The other demographic factors viz. gender and employee experience, are found to play insignificant roles in predicting employee motivational force in Academic sector.

\section{Predicting Tenure in present iob from Motivation and other Demographic Variables}

The regression equation to predict employee tenure from their motivational force and other demographic variables is given below:

Employee Motivational Force $=-6.038+4.738$ (Educational Qualification) -0.579 (Age)

Thus, it is found (refer Table 6) that in predicting employee tenure, motivational force does not play any significant role. While the positive impacts are obtained from factors such as experience and gender, each one explaining 31.8 and 34.3 percent of variance respectively, educational qualification in contrast is found to have a negative impact on employee tenure which explain 37percent of variance. As discussed earlier, the higher the qualification, the less the chance in continuing in the same job, as the people in the teaching fraternity seem to feel disenchanted with their present job and seeks change.

Thus, the findings of the present study seem to reject Null Hypothesis 5: There is no relationship whatsoever between the biographical characteristics and their tenure in present job of the employees in Academic sector.

\section{Conclusion}

Organisations across the board are conceding to the noteworthy opportunity to improve the return on investments in their human resources, by aligning strategies for employee motivation with business strategy and enhancing the value delivered to and by employees. This has been identified as critical to the ability of the organisation to firstly attract, but also most importantly retaining critical skills and adding to the organisation's competitiveness in the global market.

The research study has demonstrated that organisations need to understand that employee's job behaviour is not only related with motivation as well as different biographical variables are also associated with that. So how employees are motivated and that the organisational strategies developed should be cognoscente of the fact that those strategies would have a different motivational impact on different employees and may affect an employee in different ways at different points in time due to conditions, 
needs, personal objectives and difference in their biographical characteristics that effect their personal decisions also.

\section{Recommendations and Scope of Future Research}

The results of this study have shown a remarkable leading factor in assessing the contribution the selected factors (demographic factor) on employee motivational force and their turnover intentions. However, this study is limited in the selected technical academic institutes in India. So the external validity of the results may be limited. Factor such as organizational, personal, occupational and cultural elements, job characteristics, apart from demographic variable that may influence turnover intentions as well as employee motivation also should be explored for further research. Although this study may pose limitation in term of generalizability, however, it furthers our understanding by determining and testing the factors that relate and affect turnover intentions of the employees in the technical academic sector in India. Therefore, it is an initiative towards a greater nderstanding of organizational attitudes and behaviors particularly on employees' motivational force and their intentions to leave.

\section{References}

1. Abbasi, S., and K. Hollman. 2000. Turnover: The real bottom-line. Public Personnel Management 29 (3): 333-342.

2. Al-Mashaan, O.S. (2003). "Associations among job satisfaction, pessimism, and psychosomatic symptoms of employees in the government sector." Psychological Reports, 93, 17-25.

3. Arnold, H.J. and Feldman, D.C. 1982. "A multivariate analysis of the determinants of job turnover." Journal of Applied Psychology, 67(3): 350-360.

4. Beach, R., D. Brereton, and D. Cliff. 2003. Workforce turnover in fifo mining operations in Australia: An exploratory study. Brisbane: Brisbane Centre for Social Responsibility in Mining.

5. Berg, T.R. 1991. "The importance of equity perception and job satisfaction in predicting employee intent to stay at television stations". Group and Organization Studies, 16(3): 268-284.

6. Bernard, C.I.(1938). 'The Function of Executive.' Harvard University Press.
7. Bellenger, D.N., Wilcox, J.B. \& Ingram, T.N. (1984). "An examination of reward preferences for sales managers." Journal of Personal Selling and Sales Management, 4(2):1-6.

8. Bhargava, S. \& Kelkar, A. (2000). "Prediction of job involvement, job satisfaction, and empowerment from organizational structure and corporate culture." Psychological Studies, 45(12):43-50.

9. Bowen BE, Radhakrishna RB (1991); "Job satisfaction of agricultural education faculty: A constant phenomena" J Agr Educ, 32: 16-22.

10. Bowen, H. R., and Schuster, J. H. (1986). American professors: A national resource imperiled. New York: Oxford University Press.

11. Cotton, J and Tuttle, J (1986). "Employee turnover: A meta-analysis and review with implication for research". Academy of Management Review, 11 (1), 55-70

12. Chiu, C. (1998). "Do professional women have lower job satisfaction than professional men? Lawyers as a case study" . Sex roles, 38, (7/8), 521-537.

13. Drafke, M.W. \& Kossen, S. (1998). The human side of organisations. Reading, Massachusetts: Addison-Wesley.

14. Elaine, M. 1997. "Job tenure shift for men and women". HR Magazine, 42(5): 20.

15. Gazioglu, S. \& Tansel, A. (2002). Job Satisfaction, Work Environment and Relations with Managers in Britain. Ankara: Middle East Technical University.

16. Gerhart, B. 1990. "Voluntary turnover and alternative job opportunities". Journal of Applied Psychology, 75(5): 467-476.

17. Gouws, A. (1995). Die verwantskap tussen motivering en werkstevredenheid van 'n groep inligtingspesialiste (The relationship between motivation and job satisfaction of a group of information specialists). Unpublished M.Bib. dissertation. Rand Afrikaans University.

18. Groot, W \& Maassen van den Brink, H. (1998). Job satisfaction wages and allocation of men and women. TSER/STT Working Papers, Wp-10-98.

19. Greenberg, J., \& Baron, R.A. (1995). Behavior in organizations: Understanding and managing the 
International Journal of Trend in Scientific Research and Development (IJTSRD) ISSN: 2456-6470

human side of work (5th ed.). Trenton: PrenticeHall International, Inc.

20. Gregersen, H.B. and Black, J.S. (1982). "Antecedents to commitment to a parent company and a foreign operation". Academy of Management Journal, 35, 65-90

21. Griffeth, R. W., Hom, P. W., \& Gaertner, S. 2000. "A meta-analysis of antecedents and correlates of employee turnover: Update moderator tests, and research implications for the next millennium." Journal of Management, 26: 463-488.

22. Gouws, A. (1995). Die verwantskap tussen motivering en werkstevredenheid van 'n groep inligtingspesialiste (The relationship between motivation and job satisfaction of a group of information specialists). Unpublished M.Bib.dissertation. Rand Afrikaans University.

23. Huddleston, P., Good, L. \& Frazier, B. (2002). "The influence of firm characteristics and demographic variables on Russian workers' work motivation and job attitudes". International Review of Retail Distribution and Consumer Research, 12(4):395 - 421.

24. Hale, J. 1998. Strategic rewards: "Compensation and benefits management". Management 14 (3): 39-50.

25. Higgins, E. T., \& Spiegel, S. (2004). Promotion and prevention strategies for self-regulation:A motivated cognition perspective. In R. F. Baumeister, \& K. D. Vohs, (Eds.) Handbook of self-regulation: Research, theory, and applications. (pp. 171-187). New York: Guilford Press.

26. ILO. 2004. Promoting employment: policies, skills, enterprises. Geneva: ILO.

27. Jernigan, I.E., Beggs, J.M. \& Kohut, G.F. (2002). "Dimensions of work satisfaction as predictors of commitment type". Journal of Managerial Psychology, 17(7):564-579.

28. Johnson, G.J., \& Johnson, W.R. (2000). "Perceived over qualification and dimensions of job satisfaction: A longitudinal analysis”. Journal of Psychology, 134(5), 537-555.

29. Kovach, K A 1995. "Employee motivation: addressing a crucial factor in your organization's performance". Employment Relations Today. 22(2).
30. Lambert. E.G., Hogan, N.L., Barton, A. \& Lubbock, S.M. (2001). "The impact of job satisfaction on turnover intent: A test of a structural measurement model using a national sample of workers", Social Science Journal, 38(2), 233-251.

31. Miller, J.G. and Wheeler, K.G. 1992. "Unraveling the mysteries of gender differences in intentions to leave the organization". Journal of Organizational Behavior, 13: 465-478.

32. Mobley, W. H., "Intermediate Linkages in the Relationship Between Job Satisfaction and Employee Turnover," (1977), Journal of Applied Psychology, Vol. 62, No. 2, pp .237-240. 48.

33. Mobley, W.H., Griffeth, R.W., Hand, H.H. and Meglino, B.M. 1979. "Review and conceptual analysis of the employee turnover process". Psychological Bulletin, 86: 493-522.

34. Morrow, P (1983). "Concept redundancy in organizational research: The case of work commitment". Academy of Management Review, 8, 48-500.

35. Moon, M.J. (2000). “Organizational commitment revisited in new public management." Public Performance and Management Review, 24(2):177-194.

36. Nel, P.S., Gerber, P.D., Van Dyk, P.S., Haasbroek, G.D., Schultz, H.B., Sono, T., \& Werner, A. (2001). Human Resources Management. (5th ed.). Oxford University Press, Cape Town

37. Oosthuizen, T.F.J., (2001). "Motivation influencing worker performance in a technical division of Telkom SA", Acta Commercii, Vol. 1, 19-20.

38. Oshagbemi, T. (2000). "Gender differences in the job satisfaction of university teachers". Women in Management Review, 15(7), 331-343.

39. Oshagbemi, T. (2003). "Personal correlates of job satisfaction: empirical evidence from UK universities". International Journal of Social Economics, 30 (12), 1210-1232.

40. Pareek, U. (2002). Training Instruments in HRD and OD ( $\left.2^{\text {nd }} E d\right)$. Tata McGraw-Hill.

41. Price, J.L. and Mueller, C.W. 1986. Absenteeism and turnover of hospital employees. JAI Press Inc. 
42. Reudavey, P. G. (2001). An examination of Job Satisfaction and Employees Motivation of Ground Crew Staff within Ansett, Australia. Working Paper Series, School of Management: Curtin University of Technology.

43. Robbins, S.P. (2001). Organisational Behaviour (9th ed.). New York: Prentice-Hall, Inc.

44. Robbins, S.P.,Odendaal, A., and Roodt, G. (2003). Organizational Behavior. Global and Southern African Perspectives ( 9 th ed.). Cape Town: Pearson Education.

45. Schulze, S., \& Steyn, T., (2003). "Educator's motivation: differences related to gender, age and experience", Acta Academia, 35(3), 138-160.

46. Sekaran, U. (2000). Research methods for business: A skills building approach. ( $3^{\text {rd }} \mathrm{ed}$.). New York: John Wiley \& Sons, Inc.

47. "Service Sector in India", 21-07-2007, Indian economy.

48. Sousa-Poza, T. (2003). "Gender differences in job satisfaction in Great Britain, 1991- 2000: permanent or transitory?" Applied Economics Letters, 10(11), 691.

49. Stinson, J.E. \& Johnson, T.W. (1977). "Tasks, individual differences, and job satisfaction". Industrial Relations, 16(3):315-325.

50. Sui, O., Spector, P., Cooper, C. \& Donald, I. (2001). "Age differences in coping and locus of control: A study of managerial stress in Hong Kong". Psychology and Aging, 16, 707-710.

51. Tolbert, P.S., \& Moen, P. (1998)."Men's and women's definitions of "good" jobs".Work \&Occupations, 25(2), 168-195.

52. Summers, T.P. and Hendrix, W.H. 1991. "Modelling the role of pay equity perceptions: A field study". Journal of Occupational Psychology, 64:145-157.

53. UIS. 2007. Global Education Digest. Montreal: UIS.U.S. Department of Labor. Bureau of Labor Statistics; 2000.

54. Wai, C.T. Teresa and Robinson, C.D. 1998. "Reducing staff turnover: A case study of dialysis facilities." Health Care Management Review, 23(4): 21-42.

55. Weil, P.A. and Kimball, P.A. 1995. "A model of voluntary turnover among hospital CEOs."
Hospital and Health Service Administrative, 40(3): 362-385.

56. Weisberg, J. and Kirschenbaum, A. 1993. "Gender and turnover: A re-examination of the impact of sexon intent and actual job changes".

Human Relations, 46(8): 487-1006.

57. Williams, L.J. and Hazer, J.T. (1986), "Antecedents and consequences of satisfaction and commitment in turnover models: a re-analysis using latent variable structural equation methods", Journal of Applied Psychology, Vol. 72 No. 1, pp. 219-31. 